\title{
Adiwiyata-Based School Management in Indonesia
}

\author{
Azizul Mahendrartha \\ SMP Negeri 5 Prabumulih, Indonesia \\ e-mail: azizulmahendrartha2019@gmail.com \\ Tobari \\ Universitas Kader Bangsa, Indonesia \\ e-mail: drtobarimsi@gmail.com \\ Rommel Valencia Tabula \\ Continuing Proficiency Development Institute, Bangkok, Thailand \\ e-mail: ajarnrommel@gmail.com
}

Article History: Received on 13 July 2020, Revised on 15 July 2020, Published on 25 July 2020

\begin{abstract}
This study was to determine Adiwiyata-Based School Management in SMP Negeri 5 Prabumulih. Data were collected using observation, documentation, and interviews. While the method used is descriptive qualitative method. The results of the research indicate that (1) the implementation of the Adiwiyata Program has successfully contained a vision, mission, goals and targets which include environmental protection and management policies, (2) The Adiwiyata School Program has included the 2013 Curriculum which is carried out thematically and integrated with all environmental-based subjects, (3) participatory-based environmental activities in the Adiwiyata Program have been carried out well by all school residents in order to maintain and maintain the school building and environment, (4) the school has managed well supporting facilities that are environmentally friendly and childfriendly. The headmaster of Prabumulih 5 Middle School in the Adiwiyata School Program has been running successfully, as evidenced by the award as the 2019 Adiwiyata National School from the Ministry of the Environment.
\end{abstract}

Keywords: Adiwiyata; Environmentally Friendly Policy; Implementation of Environmental Based Curriculum; Participatory-Based Environmental Activities; Management of Green Supporting Facilities

\section{A. Introduction}

The principal has a strategic role to advance the school which begins with the planning, organization, implementation, supervision and evaluation activities. Kontagora, et al, (2017) say that in leadership, the principal plays a role in establishing school management, directing teaching staff and education staff to improve management properly. School principals are also required to be able to form a school culture with environmental education (adiwiyata program) to instill the character of accustomed to living clean, disciplined, responsible, caring for the environment and others to students so that school residents feel at home in school. Schools are the most strategic institutions as well as the spearhead in carrying out a series of educational activities to help explore the potential of students in order to realize the quality of human resources in various aspects of development. 
The school environment can be used as a means of education and inculcation of character values for school members where these values are related to human behavior related to God Almighty, self, fellow human beings, and the environment. The environment becomes an important value in the study of the application of character values in schools. As we all know that currently environmental issues have become a shared responsibility, not only the government but all citizens bear a great responsibility for environmental sustainability. Since a long time the Ministry of the Environment and the Ministry of National Education have launched an environmental education program that is packaged in the Adiwiyata Program, its implementation is regulated in Minister of Environment Regulation No. 05 of 2013 concerning Adiwiyata Implementation Guidelines. In achieving the goals of the Adiwiyata program, four program components were established that form an integrated whole in achieving Adiwiyata schools, namely (1) environmentally sound policies, (2) implementation of an environment-based curriculum, (3) participatory environment-based activities, (4) Management of environmentally friendly supporting facilities.

One of the schools in the City of Prabumulih that implements the Adiwiyata Program is SMP Negeri 5 Prabumulih. In 2019 SMP Negeri 5 Prabumulih has won the National Level Adiwiyata award from the Ministry of the Environment. According to the Ministry of Environment and the Ministry of Education and Culture (2012) the aim of the Adiwiyata program is to realize responsible school members in environmental protection and management efforts through good school governance to support sustainable development. This means that the Adiwiyata school is striving to become a school or a place for school residents to obtain knowledge, norms and ethics as a basis for creating prosperity and towards the aspirations of sustainable development. This program is expected that every school member will be involved in school activities towards a healthy environment and avoid negative environmental impacts.

The desire to form and improve attitudes and behavior that cares about the environment and the surrounding community, the school realizes it can play a role in providing knowledge and teaching students about environmental science and its management. Based on these reasons, SMP Negeri 5 Prabumulih launched various school programs to support the implementation of the Adiwiyata Program, which is daily activities without plastic, simple school WWTP processing, Healthy Canteen, Garbage Bank Processing, clean friday activity programs, compost processing programs, composters and $3 \mathrm{R}$ recycling. reuse, reduce and recycle).

This research was focused on the management of the Adiwiyata School Program in Improving the Quality of Education in SMP Negeri 5 Prabumulih, 1) Environmentally Friendly Policy; 2) Implementation of Environmental Based Curriculum; 3) ParticipatoryBased Environmental Activities; 4) Management of Green Supporting Facilities through the management functions of planning, organizing, and implementing, monitoring and evaluating. Supported by the findings of the factors driving and inhibiting the implementation of the Adiwiyata program. This research was carried out for six months.

According to Rohiat (2010) in the management process there are main functions that are displayed by a manager or leader are planning, organizing, leading, and controlling. Therefore, management is defined as the process of planning, organizing, leading, and controlling or overseeing the organization's efforts with all aspects so that organizational goals are achieved effectively and efficiently. According to Andriany (2019) management is 
a process of achieving organizational goals in an effective and efficient way through planning, organizing, leadership, and overseeing organizational resources. Meanwhile, according to Dami Ko, et al, (2018) management is the behavior and activities of hiring individuals to be more practical. Management is indispensable in modern social organizations that are characterized by scientific thinking and educational innovation. Based on the opinion of the three experts, it can be concluded that management is the process of planning, organizing, leading, and controlling to achieve organizational goals that are more practical because it is needed in modern social organizations.

The word Adiwiyata comes from two words "Adi" and "Wiyata". Adi has great meaning, great, good, ideal and perfect. Wiyata has the meaning of a place where one gets knowledge, norms and ethics in social life. (Sitisyarah and Mustika, 2017). According to the Ministry of Environment (2013) Adiwiyata has an understanding or meaning as a good and ideal place where all knowledge and various norms and ethics are obtained that can be the basis of humans towards achieving our well-being and towards the ideals of sustainable development.

The environmental activities of school culture in schools are in the form of routine and nonroutine activities, physical and non-physical activities, and activities inside and outside the school are activities carried out by the school in the process of implementing environmentally friendly school culture. The school activities are a reflection of the adiwiyata school which carries out environmental care programs in its daily activities. The adiwiyata school reflection also exists in every individual in it, the individuals in the adiwiyata school mostly have a soul of love and care for the environment, that is because the organization adopted in this case the school has adopted a school culture that is environmentally friendly.

Masaong (2011) argues that school culture is a school value system and will affect the way work is done and how school people behave. The school culture is built on deeply held beliefs about how schools should be managed or operated. School culture can be interpreted as the behavior, values and way of life of school residents. When examined further the objectives of the Adiwiyata program are aligned with the goals of environmental education. The points of the goal of environmental education are located in 6 groups 1) awareness, which gives encouragement to each individual to gain awareness and sensitivity to the environment and the problem; 2) knowledge, which helps each individual to gain a variety of experiences and basic understanding of the environment and the problem; 3 ) attitudes, namely helping each individual to obtain a set of values and abilities to get the right choices, as well as developing feelings that are sensitive to the environment and provide motivation to participate actively in the enhancement and protection of the environment; 4) skills, which help each individual to acquire skills in identifying and solving environmental problems; 5) participation, which provides motivation for each individual to actively participate in solving environmental problems; 6) evaluation, which encourages every individual to have the ability to evaluate environmental knowledge in terms of ecological, social, economic, political, and educational factors.

According to Maryani (2016) the implementation of the Adiwiyata program is laid on two principles as follows: 1) Participatory, all school components must be involved in the whole process which includes planning, implementation and evaluation according to their respective responsibilities and roles; 2) Sustainable (sustainable), all activities must be carried out in a planned, organized, and continuous manner in a comprehensive manner. 
To achieve the goals of the Adiwiyata Program, 4 (four) program components have been established that form an integrated whole in achieving the Adiwiyata School. The four components are: a. Aspects of school policies that are environmentally sound. b. Aspects of an environment based school curriculum. c. Aspects of participatory-based environmental activities. d. Aspects of managing environmentally friendly supporting facilities. The components in the Adiwiyata Program as an integrated whole mean that the links between these components cannot be separated in their implementation. The implementation of the components contained in the Adiwiyata Program of SMP Negeri 5 Prabumulih can be described as follows:

\section{Environmentally Friendly Policy}

Schools in the implementation of the Adiwiyata Program must contain a vision, mission, goals and targets that contain protection policies and environmental management. The Adiwiyata program must be summarized in learning activities that have a minimum mastery of learning related to the preservation of environmental functions, preventing pollution and environmental damage in the school and surrounding areas.

\section{Implementation of Environmental Based Curriculum}

The Adiwiyata School Program can be implemented by incorporating it into the 2013 Curriculum which is carried out thematically and integrated to all environment-based subjects. Or it can also be done by implementing making lesson plans with incoming learning methods on local and extracurricular content. Teachers and students must have competence in developing methods of environmental learning that can be carried out actively by means and methods of demonstration, group discussions, and simulations, field experiences, brainstorming or debating between students. The results of demonstrations or environmental works of students and teachers can be published at a minimum on the School Wall Magazine, website, newspaper, school bulletin, or talk shows on radio and television. Meanwhile, students can also be creative by making poems, short films, songs, pictures, research results, and related recycling products and themes related to environmental protection and management.

\section{Community-based Environmental Activities.}

Participatory-based environmental activities in the Adiwiyata Program are activities carried out by all school members in order to maintain and maintain the school building and environment. The maintenance of the school environment includes actions to take care of plants / parks, make family medicinal plants (toga), school forests, tree nurseries, fish ponds and also composting garbage. In addition, school members (teachers, staff, students and committees) are also required to carry out innovation and creativity in extracurricular activities such as Scouting, PMR, Youth Scientific Work, Little Doctors, and Nature Lovers to participate in preserving the environment, such as concrete actions undertaking composting, biogas, making biopori holes, recycling waste and paper, and making organic plant seeds. In addition, schools are also required to transmit adiwiyata school program knowledge to other schools, including by providing guidance and training, as well as visits to schools that need information and want to be part of the Adiwiyata Program family.

Management of Environmentally Friendly Supporting Facilities 
Schools that implement the Adiwiyata Program are also required to manage supporting facilities that are environmentally friendly and child-friendly. Paper reuse or recycling is an effort to support environmentally friendly in schools. For the school canteen it should be environmentally friendly, healthy, honest and child friendly, by means of the canteen it must always be clean and avoid plastic food wrapping tools, strofoam and aluminum foil. The canteen should also have a dishwasher and glass with running water. Food sold in the canteen must be free of artificial coloring agents, flavorings, preservatives, sponges that are not in accordance with health standards.

\section{B. Methods}

The method used in this research is descriptive qualitative method. According to Moleong (2013) qualitative method is a research procedure that produces descriptive data in the form of written or oral words from people and actors that are observed, directed, on an individual's background as a whole (holistically) without isolating individuals and organizations in variables or hypotheses, but view it as part of a wholeness. This research is included in descriptive qualitative research. Arikunto (2010) stated that qualitative-descriptive research is research that is intended to gather information about the status of an existing symptom, namely the state of symptoms according to what they were at the time the research was conducted. The researcher intends to describe, describe, and describe how the Principal of SMP Negeri 5 Prabumulih implements the Adiwiyata School program which is contained in four program components that form a unified whole in achieving Adiwiyata School. The four components are 1) aspects of school policies that are environmentally sound; 2) aspects of school environment-based curriculum; 3) aspects of participatory-based environmental activities; 4) Aspects of managing environmentally friendly supporting facilities. This research was carried out for six months.

To be able to obtain the data needed in this study, the authors examine the data relating to Adiwiyata program management. Data obtained from techniques: 1) observation of participation, 2) in-depth interviews, and 3) documents, with the following explanation: 1 . Observation. According to Kountor (2003) the observation method is to obtain data by observing directly so as to optimize the ability of researchers in terms of motives, beliefs, concerns, habits, and systematic recording of symptoms that appear on objects. 2. Interview. Interviews are used by researchers to assess the state of a person with a form of communication techniques directly, to get informatics and oriented data. The interview or interview technique used is a type of structured or lean interview that resembles a list of questions and written surveys, which requires the interviewer to make a framework and outlines or points that will be asked in the interview process. Preparation of these points is carried out before the interview. 3. Documentation. According to Nawawi (2006) this documentation method is a way to collect data through written relics, mainly in the form of archives and includes books on opinions, theories, propositions or laws and others relating to the problem under investigation, such as data data already in the school. This documentation method is used in research to collect data from sources in the field to obtain data such as: geographical location, history of the school's founding, photographs, infrastructure, and all matters relating to research management of the Adiwiyata program at SMP Negeri 5 Prabumulih. The next step is data analysis. According to Gunawan (2016) data analysis is an activity to organize, sort, group, mark and categorize it so that a finding is obtained based on the focus or problem to be answered. 


\section{Results and Discussion}

Principal of SMP Negeri 5 Prabumulih has been working diligently, not giving up, and never giving up so that the Adiwiyata School Program runs smoothly and successfully. Many efforts have been made to support the program, especially to implement four programs that have been successfully implemented 1) schools in the implementation of the Adiwiyata Program have successfully contained a vision, mission, goals and targets that include environmental protection and management policies; 2) the Adiwiyata School Program has included 2013 Curriculum which is carried out thematically and integrated to all environment-based subjects; 3) Participatory-based environmental activities in the Adiwiyata Program have been carried out well by all school residents in the context of maintaining and maintaining school buildings and environments. $d$. The school has managed well supporting facilities that are environmentally friendly and child-friendly.

All Adiwiyata components as explained above were successfully implemented by the Principal. This can be done because of the solid Adiwiyata management by embracing and involving teachers, staff, committees, students and other school residents. After only becoming an Adiwiyata school at the South Sumatra province level in the previous year, finally in 2019 SMP Negeri 5 succeeded in becoming a National Adiwiyata School and received an award from the Ministry of Environment of the Republic of Indonesia.

\section{Conclusion}

From the results of the study it can be concluded that the Principal management in the Adiwiyata School Program, SMP Negeri 5 Prabumulih has been going very well, smoothly, and successfully, especially the four programs that have been implemented namely; a. Aspects of school policies that are environmentally sound. b. Aspects of an environment based school curriculum. c. Aspects of participatory-based environmental activities. d. Aspects of managing environmentally friendly supporting facilities. To make this program more successful, all school members should play an active role so that the Adiwiyata School will continue to run continuously in order to achieve even higher achievements, namely the Adiwiyata Mandiri School Program which will be followed by SMP Negeri 5 Prabumulih in the years to come.

\section{E. Acknowledgement}

We would like to express our special thanks and gratitude to Principal of SMP Negeri 5 Prabumulih, Rector Universitas Kader Bangsa, and President of Continuing Proficiency Development Institute, Bangkok, Thailand who gave us the support to do this wonderful project. This project was funded independent. Secondly, we would also like to thank our friends who helped us a lot in finalizing this project within the limited time frame.

\section{REFERENCE}

Andriany, D. (2019). School Student Management Plus: Concepts, Strategies, and Implementation. Jakarta: Mitra Wacana Media.

Arikunto, S. (2010). Research Process A Practical Approach. Jakarta: Rineka Cipta.

Dami Ko, et al. (2018). Self-Management in liver transplantation. Applied Nursing Research. 
Journal of Social Work and Science Education

Volume 1 (1) 2020

E-ISSN: 2723-6919

Gunawan, I. (2016). Qualitative Research Methods Theory and Practice. Jakarta: PT Bumi Aksara.

Kontagora, et al. (2017). The Manage ment of Nigerian Primary School Teachers. International Journal of Educational Development.

Kountor, R. (2003). Research Methods for Thesis and Dissertation Writing. Jakarta: ppm.

Maryani, I. (2016). The Evaluation of the Implementation of the Adiwiyata School Program Judging from the Aspects of Participatory Activities at SDN Ungaran I Yogya karta. Journal of Elementary School Thought and Development (JP2SD), 1 (3), 170-180.

Masaong, et al. (2011). School Based Management: Theory, Models and Implementation. Gorontalo: Senta Media

Ministry of Environment and Ministry of Education and Culture. (2012). Adiwiyata Guide School of Environmental Care and Cultivation, Jawa Tengah: Badan Lingkungan Hidup.

Moleong, L. J. (2013). Qualitative Research Methods: Quantitative, Qualitative, and R\&D Approaches. Bandung: Alfa beta.

Nawawi, H. (2006). Social Field Research Instruments, Yogyakarta: Gajah Mada University Press, Third Edition.

Regulation of the Minister of Environment of the Republic of Indonesia Number 05 of 2013 concerning Guidelines for Implementation of the Adiwiyata Program.

Rohiat. (2010). School Management: Basic Theory and Practice. Bandung: PT Refika Aditama.

Sitisyarah, K., \& Mustika, R. (2017). Implementation of the Adiwiyata Program at SMP Negeri 13 Palembang. JMKSP (Jurnal Manajemen, Kepemimpinan, dan Supervisi Pendidikan, 2 (1). 